\title{
Distribution, density, and sequestration of host chemical defenses by the specialist nudibranch Tritonia hamnerorum found at high densities on the sea fan Gorgonia ventalina
}

\author{
Greg Cronin $^{1, *}$, Mark E. Hay $^{1}$, William Fenical ${ }^{2}$, Niels Lindquist ${ }^{1}$ \\ ${ }^{1}$ University of North Carolina at Chapel Hill, Institute of Marine Sciences, Morehead City, North Carolina 28557, USA \\ ${ }^{2}$ Scripps Institution of Oceanography, University of California at San Diego, La Jolla, California 92093-0236, USA
}

\begin{abstract}
The dendronotid nudibranch Tritonia hamnerorum was observed on some reefs in the Florida Keys, USA, at very high densities during the summer of 1992. T. hamnerorum specializes on the sea fan Gorgonia ventalina and sequesters the furano-germacrene julieannafuran from its host; this compound effectively protects the nudibranch from consumption by the common predatory reef fish Thalassoma bifasciatum. T. hamnerorum densities were extremely high at some locations, with as many as 1700 nudibranchs found on a single $G$. ventalina colony. A.t high densities, nudibranch feeding killed large areas on some sea fan colonies by stripping all tissue from portions of the sea fan and allowing filamentous algae and other epibionts to colonize. The density of $T$. hamnerorum on $G$. ventalina varied greatly on scales of centimeters, meters and kilometers. High density patches of nudibranchs on individual sea fans were usually composed of equivalent-sized nudibranchs. These observations suggest that pelagic veligers have an incredible capability to find and settle synchronously on one portion of a sea fan or that the larvae or juveniles hatch from egg masses and develop without leaving the sea fan. This study adds to a growing number of marine examples suggesting that feeding specialization occurs primarily among small, sedentary consumers that deter or escape predators by associating with defended hosts
\end{abstract}

KEY WORDS: Chemical defenses - Feeding specialization - Gorgonia ventalina - Nudibranch Sequestration - Tritonia hamnerorum · Tritrophic relation

\section{INTRODUCTION}

There is disagreement regarding the factors responsible for the origin of feeding specialization (Barbosa 1988, Bernays \& Graham 1988, Courtney 1988, Ehrlich \& Murphy 1988, Futuyma \& Moreno 1988, Jermy 1988, Schultz 1988, Thompson 1988), however, it is generally believed that a behavioral response to host chemistry is important in maintaining specialized associations (Futuyma 1983, Bernays \& Chapman 1987, Futuyma \& Moreno 1988, Courtney \& Kibota 1990). In terrestrial

\footnotetext{
- Present address: Dept of Biological Sciences, University of Notre Dame, Notre Dame, Indiana 46556, USA
}

communities, investigations of specialized feeding relationships have often focused on insect-plant relationships because insects comprise the majority of herbivorous species, and it has been estimated that about $90 \%$ of these insect species feed from 3 or fewer families of plants (Bernays 1989). In contrast, most marine herbivores are extreme generalists, commonly feeding on multiple divisions of plants (Hay 1992). In fact, most marine herbivores would be better classified as omnivores, as they will supplement their diet with animal matter when available (Hay 1992, Hay \& Steinberg 1992). Protection from natural enemies has been proposed as an important factor promoting feeding preferences and specialization in both terrestrial and marine systems (Hay et al. 1987, Bernays \& Graham 1988, 
Jermy 1988, Schultz 1988, Bernays 1989, Hay 1992), and sequestration of host secondary metabolites is an effective mechanism of gaining such protection (Brower et al. 1968, Jones et al. 1988, Paul \& Van Alstyne 1988, Hay et al, 1989, 1990a, Paul et al. 1990, Rogers \& Paul 1991).

Opisthobranchs are soft-bodied gastropods that are rarely attacked by the many generalist consumers with which they co-occur even though they lack the protective shell common to most gastropods (Faulkner \& Ghiselin 1983, Karuso 1987). The evolutionary trend towards a reduction or loss of shell has been attributed to their sequestering defensive secondary metabolites from dietary sources (Faulkner \& Ghiselin 1983). Carnivorous opisthobranchs, the nudibranchs, specialize on noxious invertebrates, sequestering secondary metabolites (Pawlik et al. 1988, Paul et al. 1990, Rogers \& Paul 1991, Faulkner 1992) or functional nematocysts from their prey to serve in their own defense (Conklin \& Mariscal 1977, Greenwood \& Mariscal 1984). Their herbivorous counterparts, the ascoglossans, specialize on noxious seaweeds from which they often sequester secondary metabolites (Paul \& Van Alstyne 1988, Hay et al. 1989, 1990a, Faulkner 1992, Hay 1992) and functional chloroplasts (Trench 1975, Clark et al. 1981). Unlike most marine invertebrates, opisthobranchs deposit eggs on their host or nearby substrate (Clark et al. 1979, Gibson \& Chia 1989), possibly allowing newly hatched larvae to remain near an appropriate host, especially if they develop directly and never disperse in the plankton (Thompson 1967, Bonar 1978).

Although nudibranchs are carnivorous, their association with their prey is in many ways more analogous to plant-insect interactions than prey-predator relations. Many marine invertebrate prey are like terrestrial plants in that they are (1) sessile, (2) photosynthetic (Wilkinson \& Trott 1984, Barnes 1987, Davies 1991). (3) grow in an open manner in order to gather energy, (4) produce both chemical and structural defenses against generalist consumers (Harvell \& Fenical 1989, Van Alstyne \& Paul 1992), (5) have a modular body plan (Barnes 1987), (6) can regenerate from basal portions following a dormant period (Tardent 1965), and (7) can regenerate tissue lost to disturbance or partial consumption (MacGinitie \& MacGinitie 1968, Wahle 1983). Some nudibranchs, like many specialist insects, feed on chemically noxious prey, sequester defensive compounds (Pawlik et al. 1988, Paul et al. 1990, Avila et al. 1991, Rogers \& Paul 1991. Faulkner 1992), and may have limited mobility during part of their life (i.e. insect larvae and nudibranch adults) causing them to view their host as both habitat and food. However, there is no terrestrial analogy to aeolid nudibranchs' unique ability to sequester ingested nematocysts from their coelenterate prey (i.e. insects do not transport thrichomes or thorms to their body surface).

Tritoniid nudibranchs, as a group, appear to be specialized consumers of octocorals (Gomez 1973. Birkeland 1974). In this study we concentrated on the tritrophic relation between the chemically defended (Pawlik et al. 1987, Paul \& Van Alstyne 1992) sea fan Gorgonia ventalina, its specialist nudibranch consumer (Tritonia hamnerorum), and various predatory reef fishes. Specifically we asked: (1) does $T$. hamnerorum gain protection from predators by associating with $G$. ventalina; (2) is protection from predators chemically mediated; and (3) are defensive chemicals hostderived? We also measured the natural distribution of $T$. hamnerorum during an outbreak and discuss the life history traits that could account for the distributional patterns we observed on individual colonies, among nearby colonies at a site, and among reefs scattered over a distance of about $110 \mathrm{~km}$ along the Florida Keys, USA.

\section{METHODS}

Distribution and density. From June 18 to 24,1992 , the distribution and abundance of the nudibranch Tritonia hamnerorum (Fig. 1) were measured on 7 shallow ( 1 to $7 \mathrm{~m}$ ) coral reefs east of Key Largo, Florida and at Looe Key National Marine Sanctuary, near Big Pine Key, Florida (Fig. 2). The host of T. hamnerorum, Gorgonia ventalina, was abundant at each of these sites. T. hamnerorum were about 1 to $11 \mathrm{~mm}$ in length and are described in detail by Gosliner \& Ghiselin (1987); their $G$. ventalina host can be up to $1 \mathrm{~m}$ across ( $G$. Cronin pers. obs.)

Most sites were surveyed extensively by snorkelers or SCUBA divers haphazardly selecting sea fans and measuring the density of Tritonia hamnerorum. The density of nudibranchs was determined by counting the slugs on both sides of the sea fan and measuring the maximum width and height of the sea fan. Densities were expressed as number of nudibranchs per 1sided area of the sea fan, area being estimated using the equation for the area of an ellipse $[A=1 / 4$ (width $x$ height) $\pi$ ]. To see if nudibranchs used other hosts or habitats, mangroves, grassbeds, and reef areas between 0 and $30 \mathrm{~m}$ deep were surveyed extensively by snorkelers or SCUBA divers closely observing the benthos and other potential host organisms for more than 100 diver hours.

Tritonia hamnerorum distribution and density were measured more intensively at Pickles Reef. Transects of $50 \mathrm{~m}$ length were run through 3 Gorgonia ventalina beds infested with T. hamnerorum to determine variation in nudibranch distribution on a scale of several 

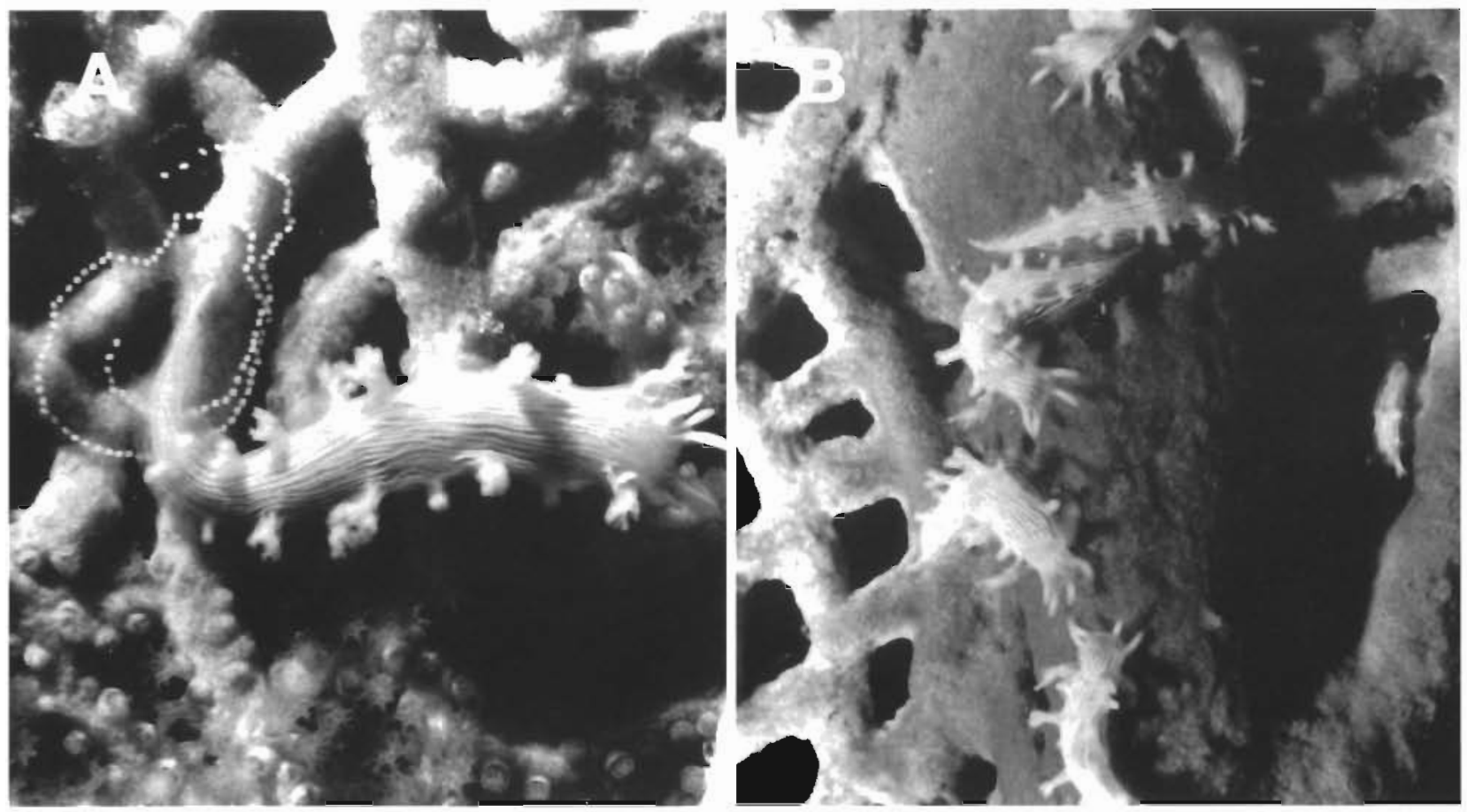

Fig. 1 Tritonia hamnerorum. (A) An adult nudibranch $(-1 \mathrm{~cm})$ next to an egg mass (eggs $140 \mu \mathrm{m}$ ) on the sea fan Gorgonia ventalina. Notice eggs have been oviposited where polyps have apparently been removed by adult feeding. (B) Five large juvenile nudibranchs $(-6 \mathrm{~mm})$ on $G$. ventalina

meters. SCUBA divers set a $50 \mathrm{~m}$ tape across the reef bottom and at $5 \mathrm{~m}$ intervals, 9 to 38 sea fans nearest the transect line were given a subjective score of 0,1 , or 2 corresponding to low, medium, or high levels of infestation, respectively. The mean level of infestation along each $5 \mathrm{~m}$ section of the transect was determined by averaging the categorical scores. To quantify our subjective visual estimates of low versus high infestation, the actual densities of nudibranchs were measured for 8 to 13 randomly chosen sea fan colonies at a low and high area of infestation along each of the 3 transects. To be sure that what we called low versus high density areas actually differed in T. hamnerorum density, the mean densities of nudibranch at these 2 areas were compared with a 2 -sample $t$-test.

Palatability and chemical defense of Tritonia hamnerorum. Because nudibranch were visually apparent to us, we guessed they would have been apparent to visual predators. To determine if Tritonia hamnerorum were susceptible to predation by common reef fishes, live nudibranchs were removed from their host and released 1 to $2 \mathrm{~m}$ above the reef where they would be investigated by fishes. Each nudibranch was followed for 1 min and its fate recorded

Because reef fishes avoided whole nudibranchs visually (see 'Results'), we destroyed the fishes ability to recognize $T$ hamnerorum visually by macerating sev- eral nudibranchs into a soft paste and forming the paste into cylinder-shaped pellets. To solidify the nudibranch paste, the gelling agent sodium alginate was mixed into the nudibranch paste at $2 \%$ of wet mass. The mixture was placed in a $250 \mu \mathrm{l}$ syringe and squirted into a mixture of $0.25 \mathrm{M} \mathrm{CaCl}_{2}$, forming a gelatinous strand $2 \mathrm{~mm}$ thick. The strand was then cut into $3 \mathrm{~mm}$ sections. Control pellets were made in a similar fashion with equal masses of macerated squid mantle and distilled water also gelled with sodium alginate added at $2 \%$ of total wet mass. A nudibranch pellet and a control squid pellet were released 1 to $2 \mathrm{~m}$ above Pickles Reef, observed for 1 min, and their fate recorded as 'consumed' if none of the pellet was visible after 1 min or 'rejected' if the pellet was tasted and spit out and part of the pellet remained at the end of 1 min. This was repeated 12 times on different areas of the reef separated by at least $4 \mathrm{~m}$ to avoid results coming from a single group of fish, and data were analyzed with Fisher's Exact Test.

The palatability of Tritonia hamnerorum to 3 species of fishes was determined using fish held in flowthrough aquaria at the National Undersea Research Center (NURC) in Key Largo. Nudibranchs were cut into small indistinct pieces to hinder the fishes' ability to recognize and avoid the nudibranch visually and they were offered to captive fishes along with a palat- 


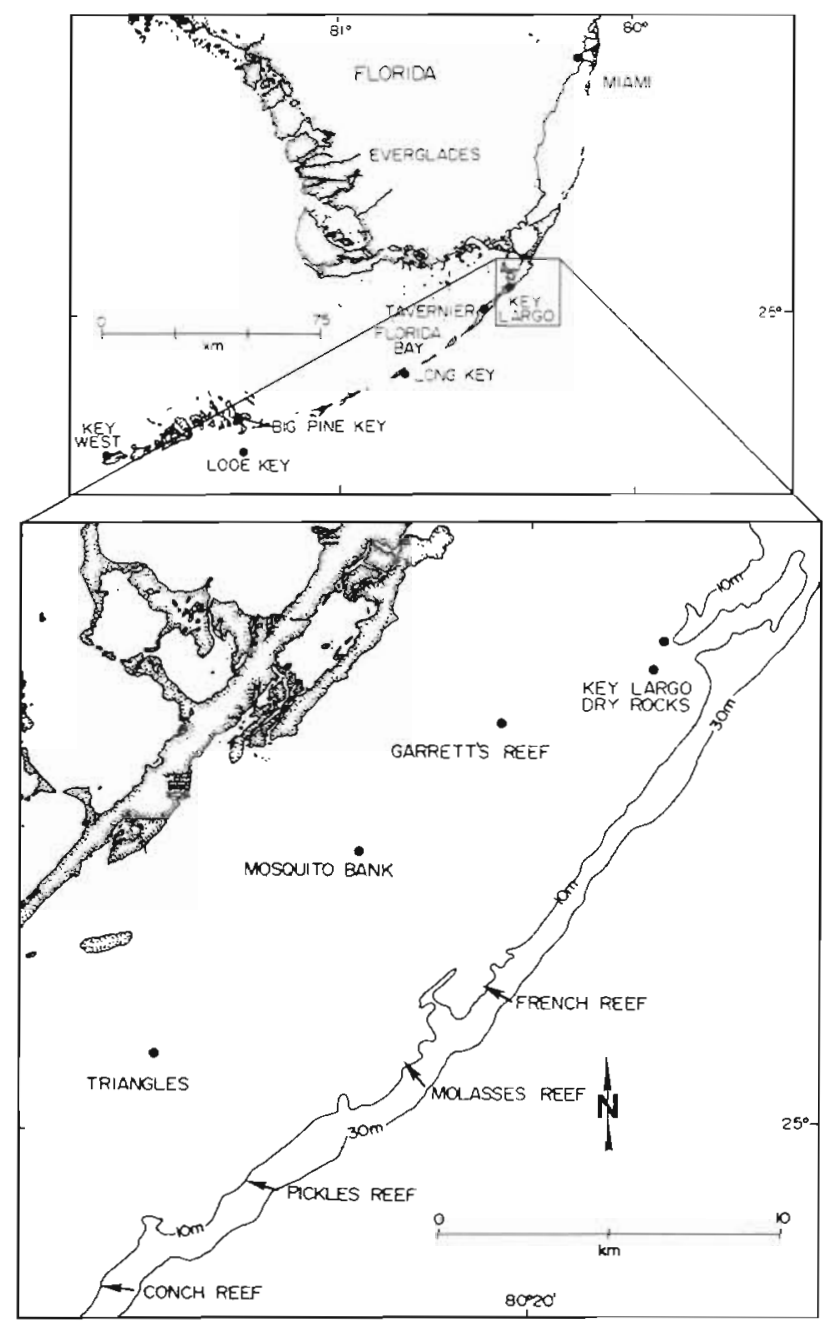

Fig. 2. Sites in south Florida, USA, where surveys of Tritonia hamnerorum were made. Field feeding assays and more intensive surveys of nudibranchs were performed at Pickles Reef. Contours $(10$ and $30 \mathrm{~m})$ are drawn to show the location of the reef platform break. Land masses are stippled

able food item as a control. Bicolor damsels Eupomacentrus partitus and juvenile grunts Haemulon sp. were held singly in separate containers and were offered brine shrimp as control food. Bluehead wrasses Thalassoma bifasciatum were held in groups of 3 to 4 fish per aquarium, usually with 1 terminal-phase male and 2 to 3 females or initial-phase males, and were offered squid pellets as controls. All fishes were fed non-assay food (freeze-dried krill) each morning so their motivation to feed during our assays was not unnaturally high. Hereafter, fishes will be referred to by their common names.

In laboratory feeding assays, each replicate fish (grunts and bicolor damsels) or group of fish (bluehead wrasses) was first offered a piece of palatable control food to determine if they were feeding. If the first con- trol item was not consumed, that replicate was not used in that assay. When the control food was consumed, a treatment food item was then offered and its fate recorded as 'eaten' or 'not eaten'. If the treatment food item was avoided or rejected (i.e. not eaten), an additional control food item was offered to determine whether the treatment item was not consumed because it was unpalatable or because the fish was no longer feeding. During the 384 feedings that comprised our 35 assays, the second control was eaten in all but 2 instances. These 2 replicates were excluded from our analyses. Because of the large number of assays performed, fishes were used in more than one assay, however, a fish or group of fish was used only once in any given assay (i.e. assays were not pseudoreplicated).

To determine if Tritonia hamnerorum was chemically defended, extracts from the nudibranchs were added to a palatable food at natural volumetric concentration (i.e. the extract from $1 \mathrm{ml}$ of nudibranch was added to $1 \mathrm{ml}$ of squid mantle food) and offered to bluehead wrasses and juvenile grunts using methods adapted from Lindquist et al. (1992). A collection of the nudibranchs (247 individuals; $3.855 \mathrm{~g}$ wet mass, $0.69 \mathrm{~g}$ dry mass, $3.42 \mathrm{ml}$ volume) was ground and extracted twice with $20 \mathrm{ml}$ of $2: 1$ dichloromethane (DCM): methanol (MeOH) and once with $7 \mathrm{ml}$ of distilled water. The $2 \mathrm{DCM}$ : MeOH extractions were combined, dried under vacuum with a rotary evaporator, and combined with the aqueous extract. The lipophilic and aqueous compounds were separated with a DCMwater partition. The DCM was removed using rotary evaporation and the water was removed by placing the aqueous phase in a desiccator filled with Drierite for $2 \mathrm{~d}$, resulting in a DCM-soluble crude extract and a water-soluble crude extract. The extracts were added to the squid-based food at natural volumetric concentrations, mixed well, and formed into $3 \mathrm{~mm}$ long pellets. Control pellets were made in an identical manner except $T$. hamerorum extracts were not added. Feeding assays were performed as described above and data were analyzed with Fisher's Exact Test. Onetailed p-values are reported because we were asking if compounds were feeding deterrents, not feeding stimulants.

After determining that Tritonia hamnerorum was defended by compounds found in the DCM-soluble extract (see 'Results'), bioassay-guided fractionation of the extract was utilized to track the deterrent compound(s). The DCM-soluble crude extract was fractionated using silica-gel flash column chromatography, with fractions being sequentially eluted with 1 columnvolume each of (1) hexanes, (2) 9:1 hexanes: diethyl ether $\left(\mathrm{Et}_{2} \mathrm{O}\right),(3) 4: 1$ hexanes: $\mathrm{Et}_{2} \mathrm{O}$, (4) $1: 1$ hexanes: $E t_{2} \mathrm{O}$, (5) $100 \% \mathrm{Et}_{2} \mathrm{O}$, and (6) $100 \%$ acetone. Each sol- 
vent mixture eluted increasingly polar metabolites from the column. The effect of each fraction on bluehead wrasse feeding behavior was determined using the methodology employed to test the crude extracts.

Feeding assays with bluehead wrasses indicated the most deterrent portion of the extract eluted with $1: 1$ hexanes: $\mathrm{Et}_{2} \mathrm{O}$ (see 'Results'). This polarity region was purified using normal-phase silica high-performance liquid chromatography IHPLC conditions: (solid phase: $10 \times 250 \mathrm{~mm}$ Rainin Microsorb column, $5 \mu \mathrm{m}$ particle size, $100 \AA$ pore size; mobile phase: $5 \%$ ethylacetate in trimethylpentane; $4 \mathrm{mI} \mathrm{min}^{-1}$ )], yielding 7 compounds. The effect of these compounds on the feeding behavior of bluehead wrasses was assessed aboard the RV 'Columbus Iselin' in the Bahamas using feeding assays as described above. Only 1 of the 7 compounds deterred bluehead wrasses, but further chemical analysis revealed that some chemical degradation had occurred. Further HPLC purification of this substance yielded the natural compound in pure form and 1 breakdown product; each of these compounds was assayed immediately with bluehead wrasses to minimize further degradation. The natural and breakdown compounds were tested separately by adding the compounds to a volume of squid equal to the volume of Tritonia hamnerorum from which the compounds originated.

The structure of the deterrent compound was determined by spectroscopic analysis. Its molecular composition was established by high-resolution fast atom bombardment (FAB) mass spectrometry, while the interconnectivities of atoms were established by 1 dimensional and 2-dimensional proton and ${ }^{13} \mathrm{C}$ nuclear magnetic resonance (NMR) methods.

Silica thin-layer chromatography (TLC) was used to qualitatively analyze the chemical profile of crude extracts, flash column fractions, and HPLC fractions. Compounds dissolved in solvent were spotted on Whatman $250 \mu \mathrm{m}$ thick PE SIL G/UV plates. TLC plates were developed in various mixtures of hexanes and $\mathrm{Et}_{2} \mathrm{O}$, depending on the polarity of the compounds. Compounds were visualized first under a UV lamp and then by spraying a fine mist of $50 \%$ sulfuric acid onto the plates followed by slow heating with an electric heat gun.

Chemical sequestration. To determine if chemical defenses in Tritonia hamnerorum were autogenic or of dietary origin, pieces of at least 20 Gorgonia ventalina colonies were collected at Pickles Reef. G. ventalina was the only host collected because it was the only prey we observed $T$. hamnerorum consuming. The sea fans were extracted in 2:1 DCM: $\mathrm{MeOH}$ and the crude extract was fractionated using flash column and HPLC procedures previously described for the nudibranch extract. The flash column fraction of the sea fan extract corresponding to the deterrent nudibranch flash column fraction yielded 6 individual compounds, 5 of which were also found in $T$. hamnerorum. The deterrent properties of the flash column and HPLC fractions from $T$ hamnerorum and $G$. ventalina were compared by performing concurrent feeding assays with bluehead wrasses aboard the RV 'Columbus Iselin' in the Bahamas.

In addition to the above collections, sections of 11 infested Gorgonia ventalina colonies and their respective Tritonia hamnerorum were collected and extracted separately in acetone. The extracts were analyzed qualitatively by HPLC using photodiode array detection (Waters 996).

In order to compare the chemistry of the specialized Tritonia hamnerorum with a generalist gorgonian predator, 2 Cyphoma gibbosum, a shelled gastropod that feeds on several gorgonians (Harvell \& Suchanek 1987), were also collected from Gorgonia ventalina, extracted, and analyzed by TLC next to $G$. ventalina and T. hamnerorum extracts.

\section{RESULTS}

\section{Distribution and density}

Tritonia hamnerorum were 1 to $11 \mathrm{~mm}$ long and their egg masses, which contained a few hundred capsules, were common on Gorgonia ventalina (Fig. 1). Each capsule contained $1 \mathrm{egg}$ and was about $140 \mu \mathrm{m}$ in diameter. When hatched in the laboratory, larvae had a well-developed gut and velum, had no yolk reserves, and began swimming upon emerging from the capsule, suggesting they were planktotrophic (J. Pawlik pers. comm.).

In June 1992, Tritonia hamnerorum were consistently found, often in high densities (means of up to 959 ind. $\mathrm{m}^{-2}$ of 1 -sided sea fan area), on Gorgonia ventalina growing on shallow ( 1 to $7 \mathrm{~m}$ ) barrier reefs along the reef platform break of the Florida Keys where turbulence and flow were high (Pickles Reef, Looe Key, and French Reef; see Fig. 2, Table 1). Although densities had not previously been documented in the Florida Keys, 2 biologists that had looked for T. hamnerorum throughout the Keys had never before seen densities approximating these. Before July 1992, T. hamnerorum were rarer with no more than 0 to 3 individuals per $G$. ventalina colony $(K$. Clark \& L. Harris pers. comm.). The reef sites we surveyed were separated by as much as $110 \mathrm{~km}$, suggesting that this outbreak of nudibranchs was widespread. During July 1992, casual observations on numerous reefs scattered throughout the Bahamas confirmed that $T$. hamnerorum was also common there but densities per area of sea fan colony 
Table 1. Sites surveyed for Tritonia hamnerorum (see Fig. 1 for location). Sites with same name indicate surveys were performed at multiple locations at that site. Method indicates whether Gorgonia ventalina colonies were chosen haphazardly or randoml: Sample size is number of sea fan colonies measured and density is given as number of nudibranch $\mathrm{m}^{-2}$ of 1 -sided sea fan area. KL: Key Largo

\begin{tabular}{|lccc|}
\hline Site & Method & $\begin{array}{c}\text { Sample } \\
\text { size }\end{array}$ & $\begin{array}{c}\text { Density } \\
\text { (mean } \pm \text { SE) }\end{array}$ \\
\hline Barrier reefs & Random & 12 & $821 \pm 241$ \\
Pickles & Random & 40 & $634 \pm 196$ \\
Pickles & Random & 15 & $604 \pm 188$ \\
Pickles & Random & 9 & $591 \pm 190$ \\
Pickles & Random & 12 & $279 \pm 84$ \\
Pickles & Random & 19 & $104 \pm 31$ \\
Pickles & Random & 35 & $35 \pm 27$ \\
Pickles & Random & 13 & $10 \pm 9$ \\
Pickles & Random & 10 & $5 \pm 5$ \\
Pickles & Random & 8 & $2 \pm 1$ \\
Pickles & Haphazard & 17 & $389 \pm 143$ \\
French Reef & Haphazard & 18 & $152 \pm 81$ \\
French Reef & Haphazard & 27 & $959 \pm 266$ \\
Looe Key & & & \\
Intermediate reeis & Haphazard & 183 & $0 \pm 0$ \\
KL Dry Rocks & Haphazard & 10 & $718 \pm 334$ \\
North KL Dry Rocks & Haphazard & 10 & $188 \pm 152$ \\
North KL Dry Rocks & Haphazard & 11 & $73 \pm 52$ \\
North KL Dry Rocks & Haphazard & 200 & $0 \pm 0$ \\
North KL Dry Rocks & Haphazard & 200 & \\
Patch reefs & & & \\
Mosquito Bank & Haphazard & 50 & $0 \pm 0$ \\
Triangles & Haphazard & 50 & $0 \pm 0$ \\
Garrett's Reef & Haphazard & 264 & $0 \pm 0$ \\
Total & & 1013 & $115 \pm 15$ \\
\hline & & & \\
\hline
\end{tabular}

seemed to be lower than in the Florida Keys (M. E. Hay pers. obs.). In contrast to the high densities and predictable occurrence of $T$. hamnerorum on barrier reefs along the seaward edge of the reef platform, we found no nudibranchs at 3 protected patch reefs 2 to $3 \mathrm{~km}$ shoreward of the platform break (Mosquito Banks, Triangles, and Garrett's Reef; see Table 1, Fig. 2) although their $G$. ventalina host was common. At Key Largo Dry Rocks, which is intermediate in exposure. no nudibranchs were found while searching 183 sea fan colonies (Table 1). Less than $1 \mathrm{~km}$ north of this site (called North KL Dry Rocks in Table 1) a large initial effort ( $n=200$ sea fans also found no nudibranchs. In further searching at this location, we found 3 small patches of sea fan where mean densities of $T$. hamnerorum ranged from 73 to 718 ind. $\mathrm{m}^{-2}$ of 1 -sided sea fan area. More than 100 diver hours of extensive observations in nearby mangroves, grassbeds, and reefs indicated that $T$. hamnerorum occurred only on $G$. ventalina.

An attempt to determine Tritonia hamnerorum host preference in the lab failed even though we used methods that had worked well with other sea slugs (Hay et al. 1990a). When the nudibranchs were placed in bowls of seawater with a selection of hosts that included Gorgonia ventalina, they crawled to the water-air interface and clung upside-down to the water surface. Because we only found the nudibranchs on reefs with considerable flow and surge, we suspect that they may have been stressed by the stagnant water conditions of our assays. Because we found $T$. hamnerorum only on $G$. ventalina despite extensive surveys of several habitats in both Florida and the Bahamas, we assume they are specialized on this sea fan. Other Tritoniids have been reported to specialize on other octocorals (Gomez 1973, Birkeland 1974).

At several shallow reef sites we surveyed, Gorgonia ventalina colonies were abundant over large areas but outbreak densities of Tritonia hamnerorum were very patchy within these sea fan beds. Fig. 3 shows resuits from three $50 \mathrm{~m}$ long transects across different locations at Pickles Reef and demonstrates that the extreme patchiness of $T$. hamnerorum occurred on a scale of meters within reefs. In the more heavily infested locations, densities of $T$. hamnerorum averaged from 279 to 821 nudibranchs $\mathrm{m}^{-2}$ of 1 -sided sea fan area. Although we did not quantify spatial variation in nudibranch densities within an individual colony, very high densities of similar-sized nudibranchs commonly occurred on one small portion of an individual sea fan. On many sea fans, we noted a few adult nudibranchs on one portion of the host and several hundred same-sized juveniles tightly aggregated on another portion of the host. For example, on one $0.27 \mathrm{~m}^{2} \mathrm{G}$. ventalina that held about $1700 \mathrm{~T}$. hamnerorum, approximately 1500 of the nudibranchs were similar-sized juveniles (about $1 \mathrm{~mm}$ ) in 1 dense aggregation that occupied no more than 10 to $15 \%$ of the host's surface. These small juveniles were so densely packed that their bodies covered almost the entire surface of the portion of the sea fan they occupied. They appeared to have eaten virtually all soft tissue from this portion of the sea fan. Within outbreak areas, we commonly observed $G$. ventalina colonies with large areas of living tissue stripped from their skeletal structure. On these colonies, there often would be a feeding front of $T$ hamnerorum with healthy $G$. ventalina in front of them and stripped skeleton behind them. This extensive and obvious damage appeared primarily on areas with high densities of juvenile nudibranchs. On $G$. ventalina with a few adult $T$. hamnerorum, the nudibranchs appeared to feed on polyps and not strip the coenenchyme from the skeletal material (Fig. 1A).

The outbreak of Tritonia hamnerorum reported above appears to have been short lived. In August 1992 (2 mo after our initial surveys), we revisited Pickles Reef and noted that densities of nudibranchs 


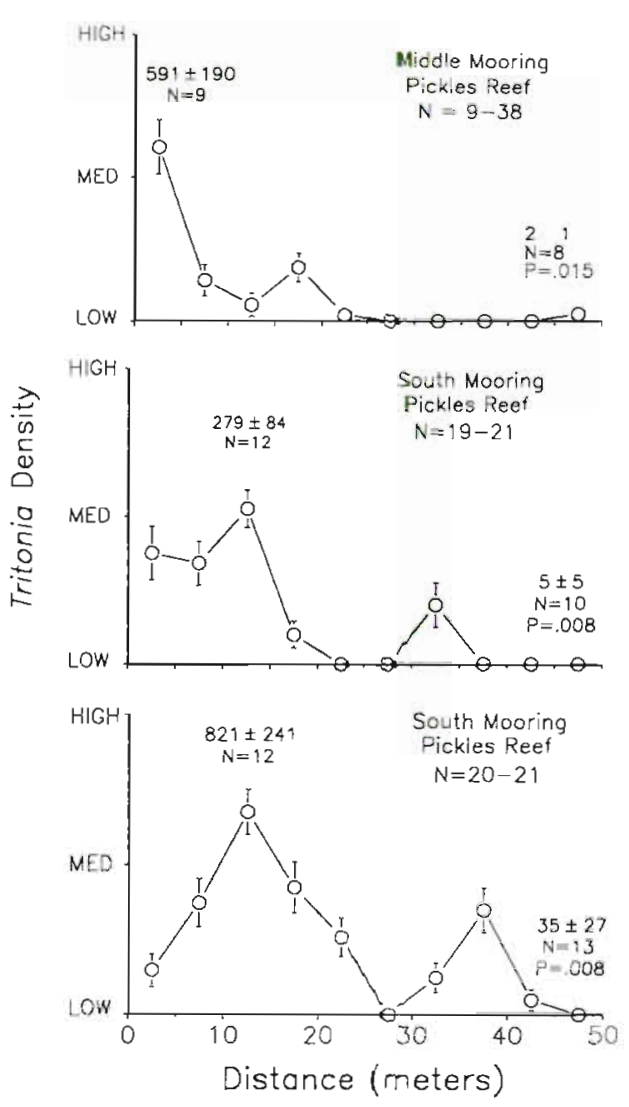

Fig. 3. Tritonia hamnerorum on Gorgonia ventalina. Distribution and density of nudibranchs on their sea fan hosts at 3 different areas of Pickles Reef. The $x$-axis represents distance along the transect and the $y$-axis is based on visual estimates of infestation (score of $0=$ low, $1=$ medium, 2 = high) scored from sea fan colonies every $5 \mathrm{~m}$ of the transect (sample size given below each site namej. For each transect, nudibranch density (ind. $\mathrm{m}^{-2}$ of 1 -sided sea fan area) was measured for randomly chosen sea fans (sample size given below each mean at each point) at a 'low' and 'med-high' area of infestation. Mean densities from 'low' and 'med-high' points were compared with a 2 -sample $t$-test and the p-value is given below the 'low' mean

seemed dramatically lower than those documented in June. We also subjectively surveyed the reef in July 1993 and found only low densities of $T$. hamnerorum.

\section{Palatability and chemical defense of Tritonia}

When 10 Tritonia hamnerorum were pulled from their hosts and released 1 to $2 \mathrm{~m}$ above the substrate at Pickles Reef they did not display swimming behavior. Groups of fishes approached the sinking nudibranchs and visually investigated them, but never attacked them. When we inhibited the ability of reef fishes to visually recognize $T$. hamnerorum by macerating the nudibranchs and forming them into cylindrical pellets that were released at different areas of Pickles Rees fishes tasted but rejected 12 nudibranch pellets; the immediately consumed 12 control pellets made di squid flesh ( $p=2 \times 10^{-7}$, Fisher's Exact Test; Fig. A A Fishes seen tasting and rejecting nudibranch pellets in the field included bluehead wrasse, bicolor damselfish and Eupomacentrus fuscus dusky damselfish

In laboratory assays, bluehead wrasses and juvemile grunts readily consumed squid pellets or brine shrimp but rejected tissue cut from individual Tritonia han:nerorum $\left(\mathrm{p}=9 \times 10^{-6}\right.$ and $8 \times 10^{-5}$, respectivel: Fig. 4B, C). In contrast, 6 of 9 bicolor damselfish consumed pieces of $T$. hamnerorum while all of the $9 \mathrm{fish}$ consumed brine shrimp (Fig. 4D). Thus, bicolor dam. selfish appeared to differ from the other 2 fishes in that they did not find nudibranchs flesh as strongly repe-lent $(p=0.051$, Fisher's Exact Test).

When lipid-soluble and water-soluble extracts from Tritonia hamnerorum were incorporated at naturill volumetric concentrations into palatable squid pellets.

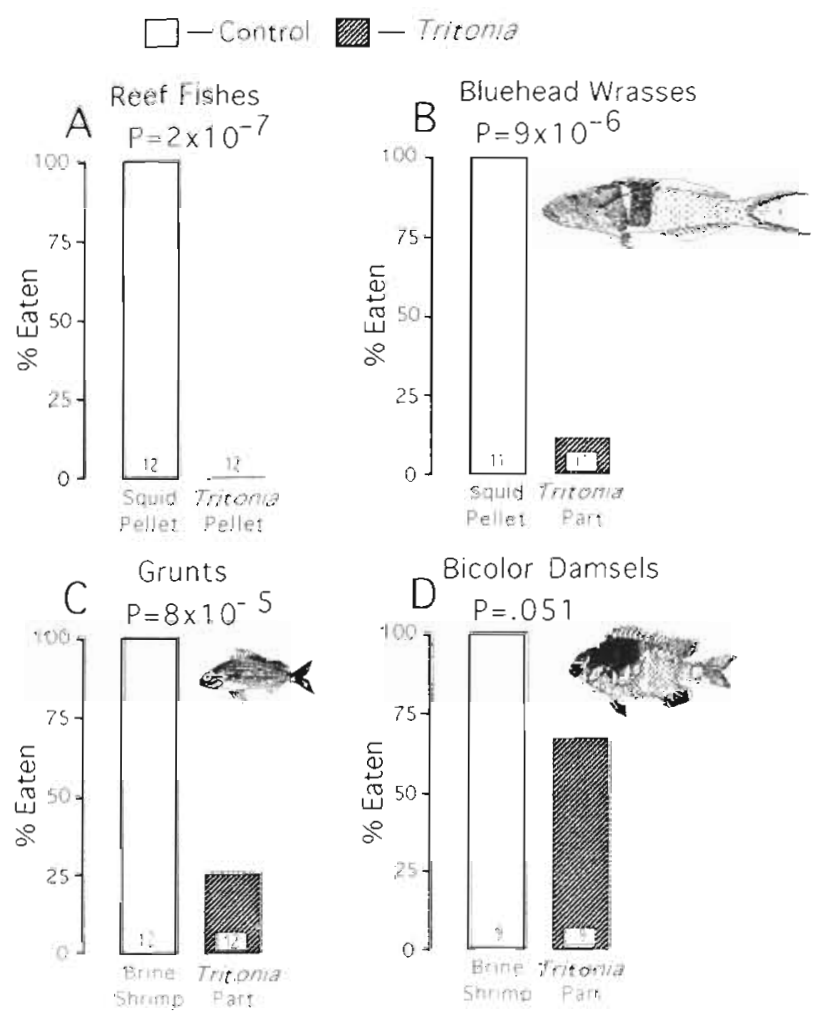

Fig. 4. Palatability of Tritonia hamnerorum pellets fed to (A) reef fishes in the field and of pieces of nudibranch tissue fed to captive (B) bluehead wrasses Thalassoma bifasciatum, (C) juvenile grunts Haemulon sp., and (D) bicolor damselfishes Eupomacentrus partitus relative to palatable controls. Open and shaded bars represent the proportion of control and test food items consumed, respectively; sample size is given within bar, and 1 -tailed $\mathrm{p}$-values are calculated from Fisher's Exact Test 
feeding by bluehead wrasses was significantly deterred by the lipid-soluble extract ( $p=0.050$, Fisher's Exact Test; Fig 5) but not by the water-soluble extract $(\mathrm{p}=0.25$, Fisher's Exact Test; Fig. 5). When the lipidsoluble extract was partitioned into 6 separate fractions differing in polarity, feeding by bluehead wrasses was decreased 75 to $85 \%$ by Fractions 3 and $4(p=8 \times$ $10^{-5}$ and $5 \times 10^{-6}$, respectively; Fig. $6 \mathrm{~A}$ ). Fraction 6 also significantly decreased feeding ( $\mathrm{p}=0.024)$ but only by $30 \%$. Feeding by grunts was also significantly diminished by the lupid-soluble extract ( $p=0.0006$, Fisher's Exact Test; Fig. 5); however, none of the flash column fractions above deterred feeding by grunts (Fig. 6B). This could be due to the elimination of additive or synergistic effects of compounds that were separated by the flash column. Also, carryover of compounds in more than 1 flash column fraction results in the compounds being present at less than natural concentration in any given fraction. For example, ILC analysis indicated that some compounds were found in 2 flash column fractions, possibly resulting in the compound being tested at $50 \%$ natural concentration in 2 separate assays. Regardless of these limitations, it is clear that bluehead wrasses were more sensitive to the flash column fractions than were the juvenile grunts (Fig 6.), even though both were significantly deterred by the DCM-soluble crude (Fig. 5)

TLC of the 6 Tritonia hamnerorum flash column fractions used in the above assay indicated a few compounds common to both Fractions 3 and 4 that could have been responsible for the large deterrence shown by the bluehead wrasses. Fraction 3 and 4 appeared

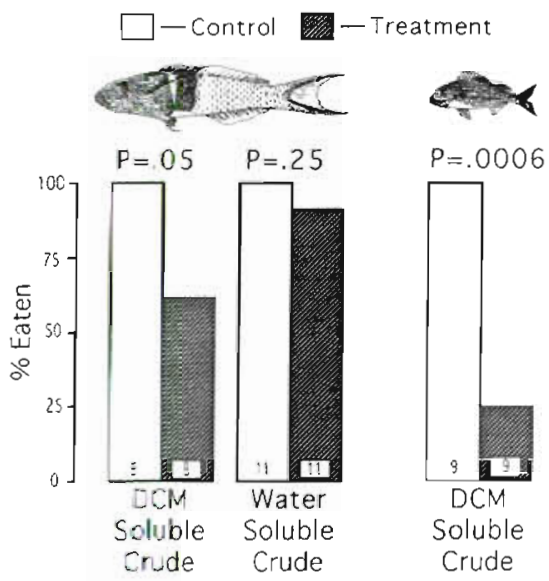

Fig. 5. Effect of dichloromethane (DCM)-soluble and watersoluble crude extracts from Tritonia hamnerorum on the feeding behavior of bluehead wrasses Thalassoma bifasciatum. Effect of the DCML-soluble extract on juvenile grunts Haemulon $\mathrm{sp}$. is also shown. Extracts were tested at natural volumetric concentrations (i. e. $1 \mathrm{ml}$ of $T$. hamnerorum extracted and this extract put into $1 \mathrm{ml}$ of squid paste). Symbols as in Fig. 4

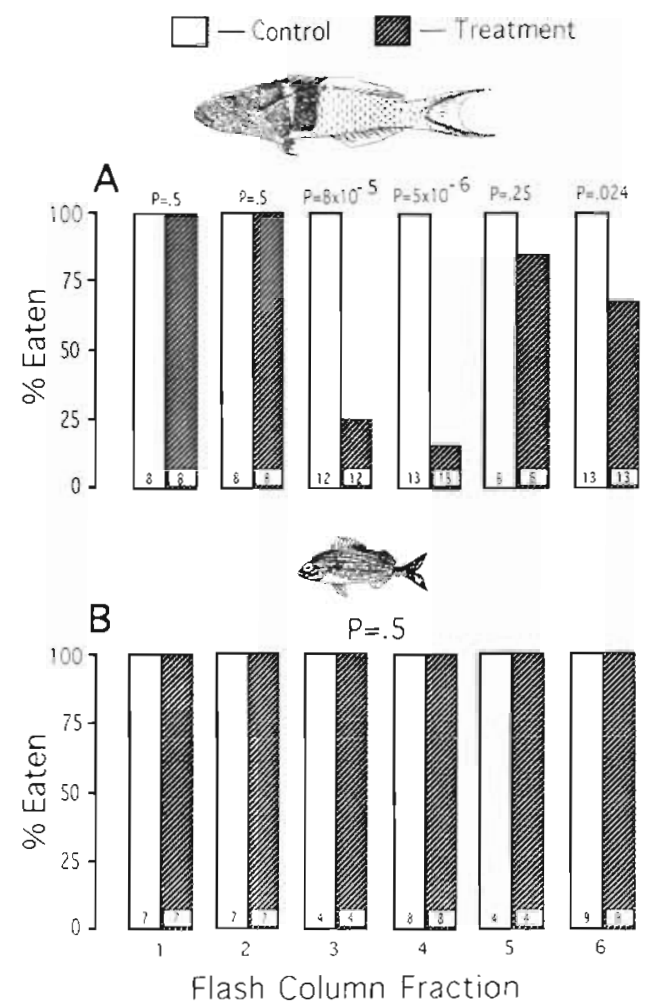

Fig. 6. Effect of flash column fractions from Tritonia hamnerorum on (A) bluehead wrasse Thalassoma bifasciatum and (B) juvenile grunt Haemulon sp. feeding behavior at natural volumetric concentrations. Polarity of flash column fractions increases from left to right. Symbols as in. Fig. 4

chemically similar with the exception of large amounts of non-polar compounds in Fraction 3 that also occurred in Fraction 2. Because Fraction 2 did not reduce feeding by bluehead wrasses, we assumed that these non-polar compounds were not deterrent. Because Fraction 4 was strongly deterrent and did not have these additional compounds, we used it for further investigations on the chemistry of the deterrent substances in $T$. hamnerorum. HPLC purification of Fraction 4 yielded 7 compounds. When the feeding effects of these compounds at natural volumetric concentrations were tested against bluehead wrasses, compound $\mathrm{F}$ depressed feeding by a significant $73 \%$ $(p=0.00001)$, while none of the other compounds affected feeding (Fig. $7 \mathrm{~A}$ ). After this assay, further HPLC investigation of this active compound indicated that it was slowly degrading and producing small quantities of a second compound. To be sure that fish were not responding to this break-down product, we used HPLC to separate and purify the 2 compounds and then immediately tested these in assays with bluehead wrasses. The natural metabolite was significantly deterrent (5 of 15 treatment pellets eaten versus 15 of 


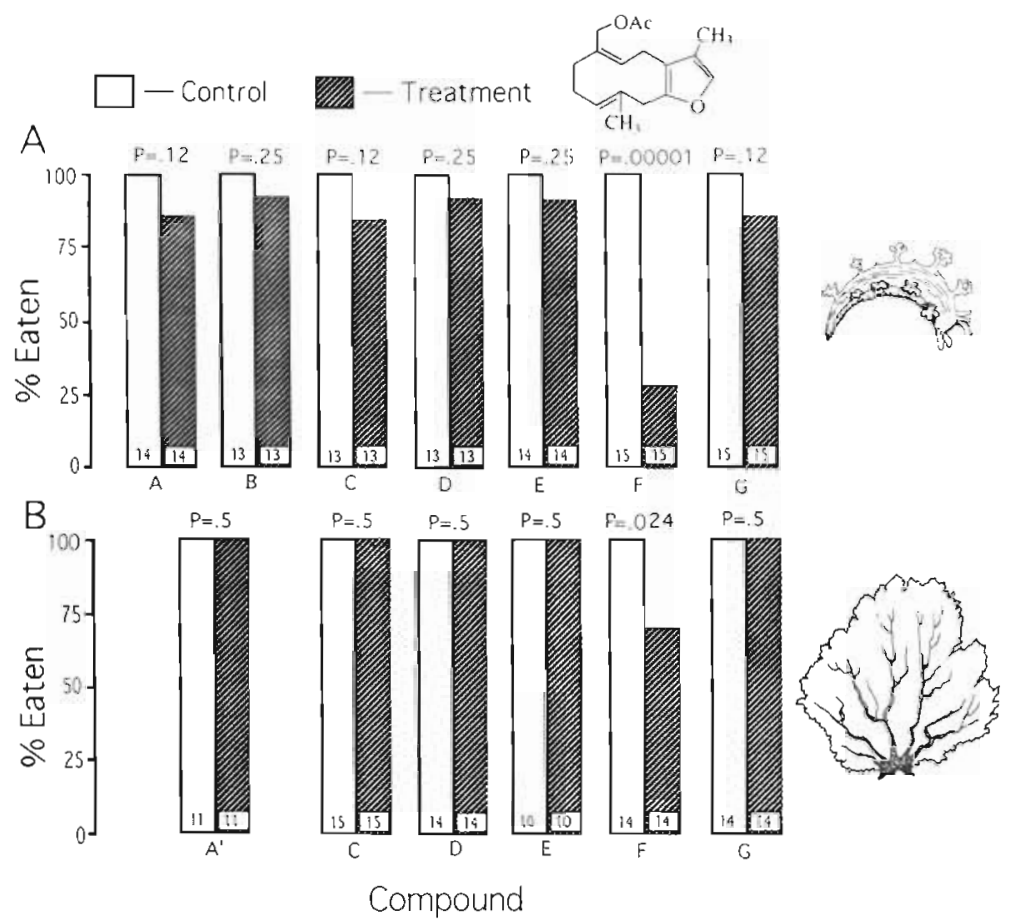

Fig. 7. Effect of individual compounds isolated from flash column Fraction 4 from (A) Tritonia hamnerorum and (B) Gorgonia ventalina on bluehead wrasse Thalassoma bifasciatum feeding behavior at natural volumetric concentrations are compared. Compounds with the same designation are identical and occur in both $T$ hamnerorum and $G$. ventalina. Structure of compound $F$, the furano-germacrene julieannafuran, is shown. Polarity of compounds increases from left to right. Other symbols as in Fig. 4

15 control pellets; $p=0.00005$, Fisher's Exact Test). In contrast, the breakdown-product was inactive (15 of 15 control and 15 of 15 treatment pellets eaten). Structural elucidation of the deterrent secondary metabolite revealed it was the furano-germacrene shown in Fig. 7. This is a previously unknown compound that we assigned the common name julieannafuran in honor of Julie Cronin, who has facilitated our research in many ways.
To see if Tritonia hamnerorum was selectively sequestering the deterrent compound relative to others in this polarity region, we repeated our flash column and preparative HPLC procedures on the lipid-soluble extract of Gorgonia ventalina. This yielded 6 compounds from the sea fan that, by TLC, corresponded to 5 of the 7 compounds we found in the nudibranchs. Yields of these compounds from T. hamnerorum and from $G$. ventalina are shown in Table 2. When compound F (julieannafuran) was tested at the volumetric concentration in sea fans, feeding diminished 29\% ( $p=0.024$, Fisher's Exact Test; Fig. 7B). None of the other compounds showed any effect at $G$. ventalina concentrations; these were also not significantly deterrent at $T$. hamnerorum concentrations. When $G$. ventalina compounds $A^{\prime}$ to $G$ were recombined and tested to see if together they might have a greater effect than any one compound alone, 4 of the 14 fish rejected the treatment pellets while all ate the control pellets; this is exactly the same result that we saw for julieannafuran alone when tested at $G$ ventalina concentration (see Fig. 7B).

TLC analysis of lipophilic extracts from Tritonia hamnerorum, Cyphoma gibbosum, and Gorgonia ventalina indicated that nudibranchs mirrored the chemical profile of their host. In contrast, the shelled $C$. gibbosum did not appear to contain $G$. ventalina metabolites. HPLC analysis of 11 $G$. ventalina colonies and their respective nudibranchs revealed that the sea fan colonies have variable chemical profiles, and that each nudibranch's chemical profile matches that of its particular host. Chromatograms of $2 \mathrm{G}$, ventalina colonies with different chemical pro-

Table 2. The concentration and ratio of individual compounds isolated from flash column Fraction 4 in Gorgonia ventalina and Tritonia hamnerorum on a dry mass, wet mass, and volumetric (Vol., $\mathrm{mg}$ compound $\mathrm{ml}^{-1}$ ind.) basis. NA: not applicable

\begin{tabular}{|c|c|c|c|c|c|c|c|}
\hline \multirow{2}{*}{$\begin{array}{l}\text { Compound } \\
\text { from } \\
\text { Fraction } 4\end{array}$} & \multicolumn{3}{|c|}{ Concentration in $T$ hamnerorum } & \multicolumn{3}{|c|}{ Concentration in G. ventalina } & \multirow{2}{*}{$\begin{array}{l}\text { T. hamnerorum: G. ventalina } \\
\text { Dry mass / Wet mass / Vol. }\end{array}$} \\
\hline & $\begin{array}{c}\% \text { dry } \\
\text { mass }\end{array}$ & $\begin{array}{l}\% \text { wet } \\
\text { mass }\end{array}$ & Vol. & $\begin{array}{l}\% \text { dry } \\
\text { mass }\end{array}$ & $\begin{array}{l}\% \text { wet } \\
\text { mass }\end{array}$ & Vol. & \\
\hline$A^{\prime}$ & 0 & 0 & 0 & 0.21 & 0.077 & 1.0 & NA \\
\hline A & 0.11 & 0.020 & 0.23 & 0 & 0 & 0 & NA. \\
\hline $\mathrm{B}$ & 0.16 & 0.028 & 0.32 & 0 & 0 & 0 & NA \\
\hline $\mathrm{C}$ & 0.23 & 0.041 & 0.46 & 0.046 & 0.017 & 0.22 & $5.0 / 2.4 / 2.1$ \\
\hline $\mathrm{D}$ & 0.15 & 0.027 & 0.31 & 0.14 & 0.051 & 0.66 & $1.1 / 0.53 / 0.47$ \\
\hline E & 0.40 & 0.072 & 0.81 & 0.31 & 0.113 & 1.5 & $1.3 / 0.64 / 0.54$ \\
\hline$F$ & 0.58 & 0.105 & 1.2 & 0.14 & 0.058 & 0.75 & $4.1 / 1.8 / 1.6$ \\
\hline $\mathrm{G}$ & 0.31 & 0.056 & 0.63 & 0.10 & 0.036 & 0.47 & $3.1 / 1.6 / 1.3$ \\
\hline
\end{tabular}




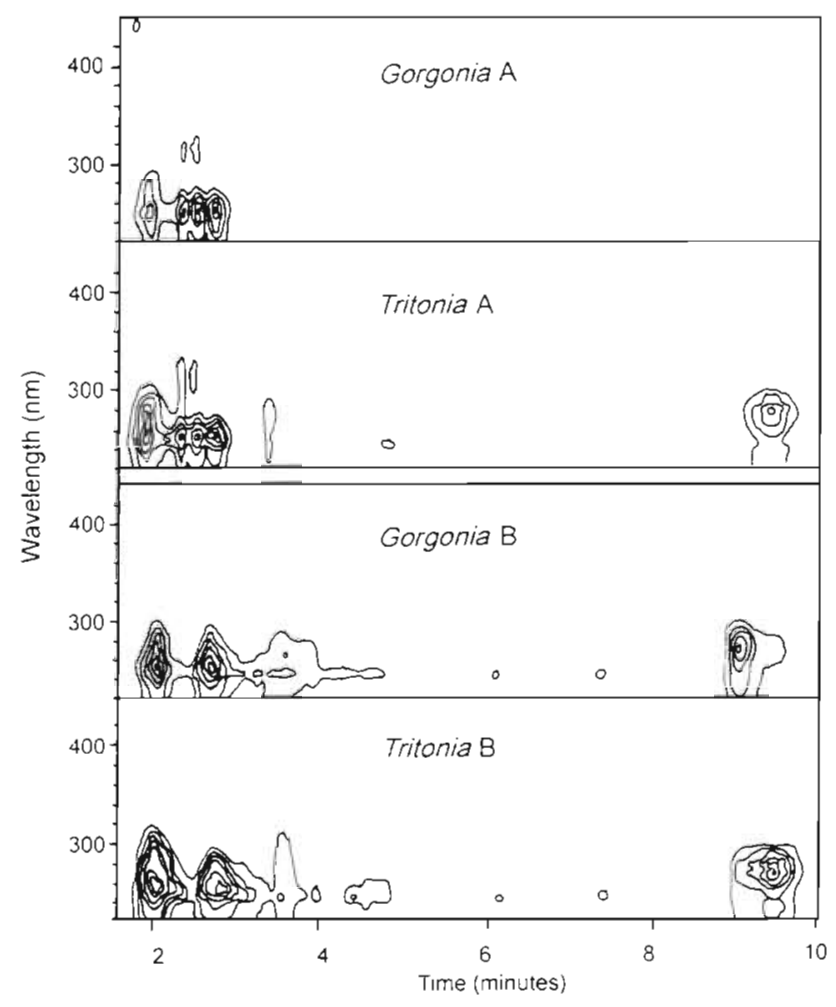

Fig. 8. The chemical profile in the polarity range of julieannafuran from 2 Gorgonia ventalina colonies and their respective Tritonia hamnerorum represented by 3 -dimensional contour HPLC chromatograms. The number of contour lines increases as the absorbance at each wavelength increases. Note the 2 $G$. ventalina colonies have qualitatively different chemical profiles; 'Gorgonia $\mathrm{A}$ ' has 4 distinct compounds eluting between 2 and 3 min and 'Gorgonia B' has only 2 major compounds eluting between 2 and 3 min plus another compound eluting at $9 \mathrm{~min}$. 'Tritonia A' contains the 4 compounds eluted between 2 and $3 \mathrm{~min}$ present in 'Gorgonia A' plus the compound eluting at $9.5 \mathrm{~min}$ while the chemical composition of

'Tritonia B' closely matches that of its host, 'Gorgonia B'

files and their respective $T$. hamnerorum are shown in Fig. 8 .

\section{DISCUSSION}

We found Tritonia hamnerorum only on the chemically defended Gorgonia ventalina (Pawlik et al. 1987. Van Alstyne \& Paul 1992) in Key Largo, however G. flabellum also has been reported as a host by other investigators (Gosliner \& Ghiselin 1987). Because previous workers in the Keys had never seen more than 1 to $3 T$. hamnerorum on a $G$. ventalina colony ( $K$. Clark \& L. Harris pers. comm.), we believe that $T$. hamnerorum was experiencing an outbreak during our study when we commonly found hundreds of nudibranch per sea fan. The previous rarity of $T$. hamnerorum probably con- tributed to its not being described until 1987 (Gosliner \& Ghiselin 1987). About 1700 nudibranch were counted on a single sea fan and sea fans with several hundred nudibranchs were common on shallow barrier reefs. These outbreak densities declined sharply within 2 mo of our measurements and remained lower 1 yr later. Also, at the high densities of nudibranch observed, they were apparently having a negative impact on their host, and it is unlikely that sea fan populations around Key Largo would be able to withstand an extended nudibranch assault of the magnitude we observed.

Tritonia hamnerorum egg capsules were $140 \mu \mathrm{m}$ diameter. In the lab, each capsule hatched as a veliger with a well-developed velum (J. Pawlik pers. comm.) suggesting that $T$. hamnerorum larvae are planktotrophic (Thompson 1967, Gosliner \& Ghiselin 1987, J. Pawlik pers. comm.). However, it seems paradoxical that planktonic larvae would result in the patchy distribution of nudibranchs we observed on scales of kilometers (Table 1), meters (Fig. 3), and within centimeters on a single Gorgonia ventalina colony. Several hundred similar-sized juveniles were often found occupying $100 \mathrm{~cm}^{2}$ of sea fan area while other portions of the same sea fan colony were free of nudibranchs (authors' pers. obs.). Possible developmental modes that could account for the patchy distribution include: (1) pelagic $T$. hamnerorum veligers exhibit size-specific gregariousness and remarkable control over where they synchronously settle (within centimeters); (2) veligers hatch from egg ribbons and develop into adults directly on the sea fan host without a pelagic phase; and (3) T. hamnerorum are poecilogonic (i.e. have more than one mode of development) and can undergo direct development.

Although gregarious settlement accurs in some marine invertebrates (Burke 1986, Pawlik 1986, 1988, 1992, Pawlik et al. 1991), we question the ability of Hypothesis 1 to explain our observations of aggregations of samesized juveniles on Gorgonia ventalina colonies. Other known cases of gregarious settlement involve larvae settling in response to chemical signals from conspecifics; this produces patches of mixed-sized individuals. We observed very localized and high density aggregates of same-sized juveniles. Patches such as these on only a small portion of an individual sea fan seem unlikely to occur due to settlement from the plankton. Hypotheses 2 and 3 cannot be dismissed based on small egg size and laboratory observations of swimming veligers. An egg size of $140 \mu \mathrm{m}$ does not preclude direct development in nudibranchs (Eyster 1979), and because adult Tritonia hamnerorum behaved much differently in the lab than they did in the field (i.e. crawling to the water-air interface rather than remaining on their host), we suspect that larvae in stagnant water might also behave abnormally and swim rather than cling to a piece of their 
host. That veligers have a well-developed velum is not inconsistent with Hypothesis 2 because the velum is used in suspension feeding as well as locomotion (Bonar 1978, Barnes 1987)

It seems logical that Tritonia hamnerorum larvae could gain many advantages by staying on their host and feeding on passing plankton rather than by floating in the plankton (i.e. Hypothesis 2). Gorgonia ventalina is a planktivore on shallow, wave-swept reefs where it grows as a lattice in a single plane perpendicular to prevailing currents (Barnes 1987). This morphology and orientation increases the plankton delivered to its feeding polyps. $T$. hamnerorum veligers could have more food transported to them on a 'plankton net' like $G$. ventalina than they would encounter if floating in the water column, where they would move with food particles. Such a benthic veliger would be assured of a host when it became an adult and might also encounter fewer planktivorous predators.

The 3 potential development types mentioned above for Tritonia hamnerorum are not mutually exclusive given some opisthobranchs are poecilogonic (i.e. Hypothesis 3). As examples, development of the ascoglossan Elysia cauze varies seasonally, with planktotrophic, lecithotrophic, and direct development occurring sequentially (Clark et al. 1979). The nudibranch Tenellia pallida lays $103 \mu \mathrm{m}$ eggs that undergo direct development or $72 \mu \mathrm{m}$ eggs that hatch as pelagic veligers (Eyster 1979), and juveniles and lecithotrophic veligers hatch from the same egg mass of the opisthobranch Haminoea callidegenita (Gibson \& Chia 1989). Bonar (1978) found 11 of 32 nudibranchs and 12 of 30 other opisthobranchs were direct developers. These studies suggest that development can be extremely variable within the opisthobranchs, but further study is needed to elucidate the development of Tritonia hamnerorum because laboratory observations of larval behavior and patterns of distribution of juveniles and adults in the field seem contradictory.

The sequestration of host chemistry is an important mechanism by which Tritonia hamnerorum gains protection from predators. Nudibranchs were avoided by abundant predatory reef fishes, and 1 compound, julieannafuran, reduced bluehead wrasse consumption by $73 \%$. TLC analysis indicated multi-individual extracts of $T$. hamnerorum and Gorgonia ventalina were chemically similar. HPLC analysis of several nudibranchs versus the individual sea fan host from which they had been collected showed that chemical profiles varied between $G$. ventalina colonies and that $T$. hamnerorum chemistry matched their individual host colony (Fig. 8). Although aeolid nudibranchs are known to sequester nematocysts from their coelenterate prey (Conklin \& Mariscal 1977, Greenwood \& Mariscal 1984), this is the first published case of a nudibranch sequestering chemical defenses from a coelenterate host. One other nudibranch, Phestilla melanobrachia, sequesters secondary metabolites from its ahermatypic coral host, Tubastrea coccinea lOkuda et al. 1986), but the ecological function of these compounds is unknown. Unlike $T$. hamnerorum, the less specialized $G$. ventalina predator, Cyphoma gibbosum, which is deterred by $G$. ventalina extracts and sclerites (Van Alstyne \& Paul 1992), did not appear to sequester deterrent compounds from its prey as evidenced by differing TLCs. However, C. gibbosum possesses a protective shell and may not need as much chemical protection from predators.

Tritonia hamnerorum not only sequestered julieannafuran, but it concentrated this compound relative to some other metabolites in Gorgonia ventalina; being $4 \times$ (dry mass basis) and $2 \times$ (wet mass basis) more concentrated in nudibranchs than in the sea fan. The nondeterrent host compounds we investigated could be either less or more concentrated in nudibranchs than in the sea fan (Table 2). At concentrations found in $G$. ventalina, julieannafuran reduced bluehead wrasse feeding only $29 \%$, but because $T$ hamnerorum concentrates the compound, it reduced feeding $73 \%$ at concentrations found in T. hamnerorum (Fig. 7A).

It appears that protection from predators and a close physical association with Gorgonia ventalina could be important factors in the evolution of feeding specificity in Tritonia hamnerorum. This study adds to the growing number of marine examples demonstrating that small, relatively non-mobile consumers gain protection from predators by associating with or specializing on noxious hosts (Hay et al. 1987, 1989, 1990a, b, Paul \& Van Alstyne 1988, Paul et al. 1990, Pennings 1990, Hay 1992, Duffy \& Hay 1994). Similar advantages appear to occur for specialist insects in terrestrial (Bernays 1989, Dyer \& Floyd 1993) and freshwater communities (Cronin et al., work in progress). This suggests that predation may select for feeding specialization in a wide variety of systems.

Acknowledgements. Funding was provided by NSF grants OCE 92-02847 (M.E.H.) and CHE 90-08621 (W.F.) and by NOAA NURC grant no. NA88AA-D-UR004 (to N.L. and M.E.H.). G.C. is grateful to his dive buddy Quaker Kappel and Mike Klompas for field and lab assistance. Steven Miller, Tom Potts, Dave Ward, and Catherine Liipfert were especially helpful during our stay at the National Undersea Research Center in Key Largo. Kerry Clark identified Tritonia hamnerorum. Joe Pawlik and Brian Chanas hatched T. hamnerorum eggs. Robin Bolser illustrated Gorgonia ventalina and $T$. hamnerorum and helped perform feeding assays. Charles Birkeland, Margaret Miller, Joe Pawlik, and 3 anonymous reviewers made helpful comments that improved the manuscript. We gratefully acknowledge the suppart of the NSF (through grant no. CHE 90-08621) which allowed our use of the RV 'Columbus Iselin' 


\section{LITERATURE CITED}

Avila, C., Cimino, G., Fontana, A., Gavagnin, M., Ortea, J. Trivellone, E. (1991). Defensive strategy of two Hyp selodoris nudibranchs from Italian and Spanish coasts J. Chem. Ecol. 17: 625-636

Barbosa, P. (1988). Some thoughts on 'the evolution of host range'. Ecology 69: 912-915

Barnes, R. D. (1987). Invertebrate zoology, 5th edn. Saunders College Publ., Fort Worth

Bernays, E. A. (1989). Host range in phytophagous insects: the potential role of generalist predators. Evol. Ecol. 3 299-311

Bernays, E. A., Chapman, R. F. (1987) Plant chemistry and acridoid feeding behavior. In: Harborne, J. B. (ed.) Coevolution of plants and animals. Academic Press, New York, p. $100-141$

Bernays, E., Graham, M. (1988). On the evolution of host specificity in phytophagous arthropods. Ecology 69 $886-892$

Birkeland, C. (1974). Interactions between a sea pen and seven of its predators. Ecol. Monogr. 44: 211-232

Bonar, D. B. (1978). Morphogenesis at metamorphosis in opisthobranch molluscs. In: Chia, F. S., Rice M. E. (eds.) Settlement and metamorphosis of marine invertebrate larvae. Elsevier, New York, p. 177-196

Brower, L. P., Ryerson, W. N., Coppinger, L. L., Glazier, S. C. (1968). Ecological chemistry and the palatability spectrum. Science 161: 1349-1351

Burke, R. D. (1986) Pheromones and the gregarious settlement of marine invertebrate larvae. Bull. mar. Sci. 39: $323-331$

Butman, C. A. (1987). Larval settlement of soft-sediment invertebrates: the spacial scales of pattern explained by active habitat selection and the emerging role of hydrodynamical processes. Oceanogr. mar. Biol. A. Rev. 25: $113-165$

Butman, C. A., Grassle, J. P. (1992). Active habitat selection by Capitella sp. I larvae. I. Two-choice experiments in still water and flume flows. J. mar. Res. 50: 669-715

Butman, C. A., Grassle, J. P., Webb, C. M. (1988). Substrate choices made by marine larvae settling in still water and in a flume flow. Nature 333: 771-773

Clark, K. B., Busacca, M., Stirts, H. (1979). Nutritional aspects of development of the ascoglossan, Elysia cauze. In: Stancyk, S. E. (ed.) Reproductive ecology of marine invertebrates. Univ. of South Carolina Press, Columbia, p. 11-24

Clark, K. B., Jensen, K. R., Stirts, H. M., Fermin, C. (1981). Chloroplast symbiosis in a nonelysiid mollusc, Costasiella lilianae Marcus: effects of temperature, light intensity, and starvation on carbon fixation rate. Biol. Bull. 160: 43-54

Conklin, E. J., Mariscal, R. N. (1977). Feeding behavior, ceras structure, and nematocyst storage in the aeolid nudibranch, Spurilla neapolitana (Mollusca). Bull. mar. Sci. 27: $658-667$

Courtney, S. (1988). If it's not coevolution, it must be predation? Ecology 69: 910-911

Courtney, S. P., Kibota, T. T (1990). Mother doesn't know best: selection of hosts by ovipositing insect. In: Bernays, E. A. (ed.) Insect-plant interactions, Vol. II. CRC Press, Boca Raton, p. 161-188

Davies, P. S. (1991). Effects of daylight variations on the energy budgets of shallow water corals. Mar. Biol. 108: $137-144$

Duffy, J. E., Hay, M. E. (1994). Herbivore resistance to seaweed chemical defense: the roles of mobility and predator risk. Ecology 75: 1304-1319
Dyer, L. A., Floyd, T (1993). Determinants of predation on phytophagous insects: the importance of diet breadth. Oecologia 96: 575-582

Ehrlich, P. R, Murphy, D. D. (1988). Plant chemistry and host range in insect herbivores. Ecology 69: 908-909

Eyster, L. S. (1979). Reproduction and developmental variability in the opisthobranch Tenellia pallida. Mar. Biol. 51: $133-140$

Faulkner, J. D. (1992). Chemical defense of marine molluscs. In: Paul, V. J. (ed.) Ecological roles of marine natural products. Cornell University Press, Ithaca, p. 119-163

Faulkner, J. D., Ghiselin, M. T. (1983). Chemical defense and evolutionary ecology of dorid nudibranchs and some other opisthobranch gastropods. Mar. Ecol. Prog. Ser. 13: 295-301

Futuyma, D. J. (1983). Evolutionary interactions among herbivorous insects and plants. In: Futuyma, D. J, Slatkin, M. (eds.) Coevolution. Sinauer Associates, Sunderland, MA, p. $207-231$

Futuyma, D. J, Moreno, G. (1988). The evolution of ecological specialization. A. Rev. Ecol. Syst. 19: 207-233

Gibson, G. D, Chia, F. S (1989). Developmental variability (pelagic and benthic) in Haminoea callidegenita (Opisthobranchia: Cephalaspidae) is influenced by egg mass jelly. Biol. Bull. 176: 103-110

Gomez, E. D. (1973). Observations on feeding and prey specificity of Tritonia festiva (Stearns) with comments on other Tritoniids (Mollusca: Opisthobranchia). Veliger 16: $163-165$

Gosliner, T. M., Ghiselin, M. T. (1987). A new species of Tritonia (Opisthobranchia: Gastropoda) from the Caribbean Sea. Bull. mar. Sci. 40:428-436

Greenwood, P. G., Mariscal, R. N. (1984). Immature nematocyst incorporation by the aeolid nudibranch Spurilla neapolitana. Mar. Biol. 80: 35-38

Harvell, C. D., Fenical, W. (1989). Chemical and structural defenses of Caribbean Gorgonians (Pseudopterogorgia spp.) intracolony localization of defense. Limnol. Oceanogr. 34 $382-389$

Harvell, C. D. Suchanek, T. H. (1987). Partial predation on tropical Gorgonians by Cyphoma gibbosum (Gastropoda) Mar. Ecol. Prog. Ser. 38: 37-44

Hay, M. E. (1992). The role of seaweed chemical defenses in the evolution of feeding specialization and in the mediation of complex interactions. In: Paul, V. J. (ed.) Ecological roles of marine natural products. Cornell University Press, Ithaca, p. 93-118

Hay, M. E., Duffy, J. E., Fenical, W. (1990b). Host-plant specialization decreases predation on a marine amphipod: an herbivore in plant's clothing. Ecology 71:733-743

Hay, M. E., Duffy, J. E., Paul, V. J., Renaud, P. E., Fenical, W (1990a). Specialist herbivores reduce their susceptibility to predation by feeding on the chemically defended seaweed Avrainvillea longicaulis. Limnol. Oceanogr 35 $1734-1743$

Hay, M. E., Duffy, J. E., Pfister, C. A., Fenical, W. (1987). Chemical defenses against different marine herbivores: are amphipods insect equivalents? Ecology 68: 1567-1580

Hay, M. E., Fenical. W. (1988). Marine plant-herbivore interactions: the ecology of chemical defense. A. Rev. Ecol. Syst. 19: 111-145

Hay, M. E., Pawlik, J. R., Duffy, J. E., Fenical, W. (1989). Seaweed-herbivore-predator interactions: host-plant specialization reduces predation on small herbivores. Oecologia 81: $418-427$

Hay, M. E., Steinberg, P. D. (1992) The chemical ecology of plant-herbivore interactions in marine versus terrestrial 
communities. In: Rosenthal, G. A., Berenbaum, M. R. (eds.) Herbivore: their interactions with secondary plant metabolites, 2E, Vol. II: Evolutionary and ecological processes Academic Press, New York, p. 371-413

Jermy, $T$ (1988). Can predation lead to narrow food specialization in phytophagous insects? Ecology 69: 902-904

Jones, C. G., Whitman, D. W., Silk, P. J., Blum, M. S. (1988). Diet breadth and insect chemical defenses: a generalist grasshopper and general hypotheses. In: Spencer, K. C. (ed.) Chemical mediation of coevolution. Academic Press New York, p. 477-512

Karuso, P. (1987). Chemical ecology of the nudibranchs. In Scheuer, P. J. (ed.) Bioorganic marine chemistry, Vol. 1. Springer-Verlag, New York, p. 31-60

Lindquist, N., Hay, M. E. Fenical, W. (1992). Defense of ascidians and their conspicuous larvae: Adult vs. larval chemical defenses. Ecol. Monogr. 62: 547-568

MacGinitie, G. E., MacGinitie, N. (1968). Natural history of marine animals, 2nd edn. McGraw-Hill Book Co., New York

Okuda, R. K., Gulavita, N. K., Scheuer, P. J., Matsumoto, G. K., Rafii, S., Clardy, J. (1986). Secondary metabolites of marine organisms. In: Atta-ur-Rahman, Le Quesne, P. W. (eds.) New trends in natural products chemistry 1986, Studies in organic chemistry, Vol. 26. Elsevier Science Publishers, Amsterdam, p. 417-433

Paul, V. J., Lindquist, N., Fenical, W. (1990). Chemical defenses of the tropical ascidian Atapozoa sp. and its nudibranch predators Nembrotha spp. Mar. Ecol. Prog. Ser. 59: $109-118$

Paul, V J., Van Alstyne, K. L. (1988). Use of ingested algal diterpenoids by Elysia halimedae Macnae (Opisthobranchia: Ascoglossa) as anti-predator defense. J. exp. mar. Biol. Ecol. 119: 15-29

Pawlik, J. P. (1986). Chemical induction of larval settlement and metamorphosis in the reef-building tube worm Phragmatopoma californica (Polychaeta: Sabellariidae). Mar. Biol. 91: 59-68

Pawlik, J. P. (1988). Larval settlement and metamorphosis of sabellariid polychaetes, with special reference to Phragmatopoma lapidosa, a reef-building species, and Sabellaria floridensis, a non-gregarious species. Bull. mar. Sci. 43: $41-60$

Pawlik, J. P. (1992). Chemical ecology of the settlement of benthic marine invertebrates. Oceanogr. mar. Biol. A. Rev. 30: $273-335$

This article was presented by C. Birkeland (Senior Editorial Advisor), Mangilao, Guam
Pawlik, J. R., Burch, M. T., Fenical, W. (1987). Patterns of chemical defense among Caribbean Gorgonian corals: a preliminary survey. J. exp. mar. Biol. Ecol. 108: 55-66

Pawlik, J. R., Butman, C. A., Starkzac, V. R. (1991). Hydrodynamic facilitation of gregarious settlement of a reef-building tube worm. Science 251:421-424

Pawlik, J. R., Kernan, M. R., Molinski, T F., Harper, M. K., Faulkner, D. J. (1988). Defensive chemicals of the Spanish dancer nudibranch Hexabranchus sanguineus and its egg ribbons: macrolides derived from a sponge diet. J. exp. Mar. Biol. Ecol. 119:99-109

Pennings, S. C. (1990). Multiple factors promoting narrow host range in the sea hare, Aplysia californica. Oecologia 82: $192-200$

Rogers, S. D., Paul, V. J. (1991). Chemical defenses of three Glossodoris nudibranchs and their dietary sponges. Mar. Ecol. Prog. Ser. 77: 221-232

Schultz, J. C. (1988). Many factors influence the evolution of herbivore diets, but plant chemistry is central. Ecology 69: $896-897$

Tardent, P. (1965). Developmental aspects of regeneration in coelenterates. In: Kiortsis, V., Trampusch, H. A. L. (eds.) Regeneration in animals and related problems. NorthHolland Publ. Co., Amsterdam, p. 71-88

Thompson, J. N. (1988). Coevolution and alternative hypotheses on insect/plant interactions. Ecology 69: 893-895

Thompson, T. E. (1967). Direct development in a nudibranch, Cadlina laevis, with a discussion of developmental processes in Opisthobranchia. J. mar. biol. Ass. U.K. 47 : $1-22$

Trench, R. K. (1975). Of leaves that crawl: functional chloroplasts in animal cells. In: Jenning, D. H., Lee, D. L. (eds.) Symbioses. Cambridge University Press, Cambridge, p. 229-265

Van Alstyne, K. L., Paul, V. J. (1992). Chemical and structural defenses in the sea fan Gorgonia ventalina: effects against generalist and specialist predators. Coral Reefs 11. $155-159$

Wahle, C. M. (1983). Regeneration of injuries among Jamaican Gorgonians: the roles of colony physiology and environment. Biol. Bull. 165: 778-790

Wilkinson, C. R., Trott, L. A. (1984). Light as a factor determining the distribution of sponges across the central Great Barrier Reef. Proc. 5th Int. Coral Reef Congr. 5: $125-130$

Manuscript first received: April 7, 1994

Revised version accepted: September 14, 1994 